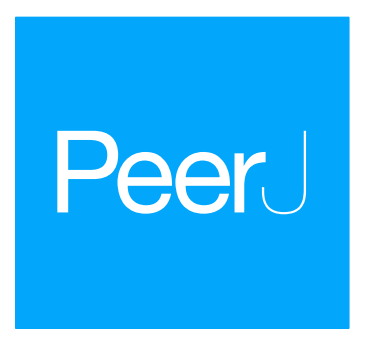

Submitted 28 February 2018

Accepted 4 April 2019

Published 13 May 2019

Corresponding author

Sarah Caronni,

sarah.caronni@unipv.it

Academic editor

Craig Nelson

Additional Information and Declarations can be found on page 13

DOI 10.7717/peerj.6908

Copyright

2019 Caronni et al.

Distributed under

Creative Commons CC-BY 4.0

OPEN ACCESS

\section{The interactive effect of herbivory, nutrient enrichment and mucilage on shallow rocky macroalgal communities}

\author{
Sarah Caronni ${ }^{1}$, Chiara Calabretti ${ }^{1}$, Sandra Citterio ${ }^{1}$, Maria Anna Delaria ${ }^{2}$, \\ Rodolfo Gentili ${ }^{1}$, Giovanni Macri ${ }^{3}$, Chiara Montagnani ${ }^{1}$, Augusto Navone ${ }^{4}$, \\ Pieraugusto Panzalis ${ }^{4}$, Giulia Piazza ${ }^{1}$ and Giulia Ceccherelli ${ }^{2}$ \\ ${ }^{1}$ Department of Earth and Environmental Sciences, University of Milan-Bicocca, Milan, Italy \\ ${ }^{2}$ Department of Science for Nature and Environmental Resources, University of Sassari, Sassari, Italy \\ ${ }^{3}$ Mac Pro e Gis, Pavia, Italy \\ ${ }^{4}$ Marine Protected Area of Tavolara Punta Coda Cavallo, Olbia, Italy
}

\section{ABSTRACT}

This paper focuses on the interactive short and long-term effect of three different stressors on a macroalgal assemblage. Three stressors are considered: herbivory, nutrients and mucilage. The experiment was conducted in Tavolara Punta Coda Cavallo Marine Protected Area (Mediterranean Sea) during a bloom of the benthic mucilageproducing microalga Chrysophaeum taylorii (Pelagophyceae); this microalga is recently spreading in the Mediterranean Sea. On a rocky substratum, 36 plots $20 \times 20 \mathrm{~cm}$ in size were prepared. Factorial combinations of three experimental treatments were applied in triplicate, including three grazing levels crossed with two nutrient enrichment and two mucilage removal treatments. Significant differences were observed among treatments 8 weeks later, at the end of summer. In particular, dark filamentous algae were more abundant in all enriched plots, especially where mucilage and macroalgae had been removed; a higher percent cover of crustose coralline algae was instead observed where nutrients had been increased and no grazing pressure acted. Furthermore, the abundance of Dictyota spp. and Laurencia spp. was significantly higher in enriched mucilage-free plots where the grazing pressure was null or low. However, the effects of the treatments on the overall assemblage of the macroalgal community were not long persistent (36 weeks later). These results illustrate the capacity of a shallow-water macroalgal community to quickly recover from the simultaneous impacts of herbivory, nutrient enrichment, and mucilage.

Subjects Ecology, Marine Biology, Plant Science, Environmental Impacts

Keywords Multiple stressors, Mediterranean Sea, Macroalgae, Interactive effects, Mucilage

\section{INTRODUCTION}

Marine ecosystems and especially near-shore coastal areas are typically subjected to several natural and anthropogenic abiotic and biotic stressors, which can seriously affect the structure of habitats and produce nearly irreversible shifts, leading to a significant reduction of ecosystem resistance and resilience (Adams, 2005; Claudet \& Fraschetti, 2010; Guarnieri et al., 2014). A substantial research effort has therefore been done to investigate the effects of the most widespread threats to marine environment (Crain et

How to cite this article Caronni S, Calabretti C, Citterio S, Delaria MA, Gentili R, Macri G, Montagnani C, Navone A, Panzalis P, Piazza G, Ceccherelli G. 2019. The interactive effect of herbivory, nutrient enrichment and mucilage on shallow rocky macroalgal communities. PeerJ 7:e6908 http://doi.org/10.7717/peerj.6908 
al., 2009); anyway, understanding the complex effects of multiple stressors on marine communities still represents one of the major challenges in marine ecology (Sala et al., 2000; Zeidberg \& Robinson, 2007; Guarnieri et al., 2014). Moreover, whether stressors are more harmful in combination than alone is still widely unanswered (Zeidberg \& Robinson, 2007). Interactions among multiple stressors, where often the ecological effect of one stressor depends on the magnitude of another, are very common across ecosystems (Jackson et al., 2016) and several scenarios can occur when they simultaneously act: their effects can be cumulative, synergistic or antagonistic (Vinebrooke et al., 2004). Two or more stressors are defined as cumulative if their result is the mere sum of the effects of each of them (combined effect: stressor $a+$ stressor $b$ ), while they are synergistic or antagonistic when their combined effect is respectively larger or smaller than the one expected by each of them (synergistic $=$ combined effects are larger than adding stressor $\mathrm{a}+$ stressor $\mathrm{b}$; antagonistic $=$ combined effects are lower than adding stressor $\mathrm{a}+$ stressor $\mathrm{b})(\mathrm{Crain}$, Kroeker \& Halpern, 2008). For example, pH usually can have an antagonistic effect on heavy metal availability in water environments, as the heavy metal solubility normally increases when $\mathrm{pH}$ decreases (Millero et al., 2009). On the contrary, a synergistic effect has been described for Daphnia: Folt et al. (1999) observed that the reproduction rate of the crustacean increased when high temperatures and food levels were simultaneously present, while the positive effect of temperature on the population growth rate was smallest at limiting food levels (Folt et al., 1999).

In coastal ecosystems, canopy macroalgae play critical ecological roles (Koch et al., 2013), contributing significantly to total primary production and deeply affecting higher trophic levels (Graham, 2004). In fact, they provide the three-dimensional structure of marine faunal habitats and facilitate larval settlement of marine invertebrates (Rodríguez, Ojeda \& Inestrosa, 1993). In the last decades, shallow temperate reefs are experiencing a dramatic reduction and loss of macroalgal habitats and their replacement by persistent barren grounds are of increasing concern (Guidetti et al., 2003; Sala et al., 2012). Several studies highlighted the importance of herbivore pressure in defining the composition and the abundance of macroalgal communities (i.e., Karez et al., 2004; Arévalo, Pinedo $\&$ Ballesteros, 2007). In particular, the abundance of herbivores (mainly sea-urchins and limpets) increases in relation to over-exploitation by large-sized predators, producing a rapid shift in dominance from canopy forming to crustose macroalgae with the creation of persistent barrens worldwide (Filbee-Dexter \& Scheibling, 2014; Piazzi, Bulleri \& Ceccherelli, 2016). However, not only herbivore pressure but also nutrient enrichment can alter the structure of benthic communities (Smith, Hunter \& Smith, 2010) and it can determine macroalgal abundance, even if its importance is extensively debated (i.e., McGlathery, 2001; Armitage et al., 2005). Recently, it has been suggested that nutrient enrichment may mitigate over-grazing by enhancing algal growth (Boada et al., 2017).

The relationship between nutrient enrichment and microalgal abundance has been extensively described in literature (e.g., Hecky \& Kilham, 1988; Anderson, Glibert $\&$ Burkholder, 2002), as nutrient enrichment is an important driver of microalgal proliferation (Smith \& Schindler, 2009). There are numerous examples worldwide of harmful algal blooms linked to an increased nutrient loading and there is a growing 
consensus that degraded water quality caused by nutrient pollution, in particular by $\mathrm{N}$ compounds, contributes to the development and persistence of microalgal proliferations and, consequently, of mucilage abundance (Obernosterer \& Herndl, 1995; Rinaldi et al., 1995). The presence of the mucilage corresponds to the appearance of a gelatinous material suspended in marine waters (pelagic aggregates) or covering large portions of the substratum (benthic aggregates); it is primarily produced by planktonic or benthic microalgae respectively (Mingazzini \& Thake, 1995). Mucilage is a problem during blooms when microalgae proliferate rapidly, reaching very high-density, and covering large portions of substrata, as described by Schiaparelli et al. (2007) or Lugliè et al. (2008).

Detrimental effects due to mucilage proliferation can affect macroalgae and other benthic organisms and should therefore be considered an emerging threat to coastal ecosystems (Claudet \& Fraschetti, 2010). In fact Devescovi \& Iveša (2007) observed that primary branches of macroalgae usually show signs of necrosis after blooms (Devescovi \& Iveša, 2007) and Misic, Schiaparelli \& Covazzi Harriague (2011) assert that the persistence of mucilage on hard substrata can overgrow algae and cause their depletion. Finally, thick mucilage carpet that usually covers the substratum during blooms can be gradually torn off by the continuous twisting action of currents, engulfing and mechanically detaching macroalgae (Schiaparelli et al., 2007). Nevertheless, only a few papers describe the detailed effects of mucilage on macroalgal communities, and currently no information about effects of the interaction among nutrient enrichment, herbivory and mucilage on the above-mentioned communities are available in literature.

In this paper, results of a manipulative experiment to evaluate the interactive short- and long-term effect of the three above mentioned stressors (herbivory, nutrient enrichment and mucilage) on macroalgal assemblages are presented. The experiment was conducted during a bloom of the benthic mucilage-producing microalga Chrysophaeum taylorii Lewis and Bryan (Pelagophyceae), recently spreading in the Mediterranean Sea (Caronni et al., 2014; Caronni et al., 2015). C. taylorii can exude large amounts of mucilaginous material


et al., 2014). Although it is considered a public nuisance also in its native range (Atlantic and Pacific Ocean), its blooms are infrequent there (at least in the Great Barrier Reef) and their effects are not so detrimental as those of other microalgae (e.g., Schaffelke et al., 2004). Conversely, in the Mediterranean Sea, large portions of hard rocky and sandy substrata as well as seagrasses and macroalgae can be covered by $C$. taylorii mucilage during summer (Lugliè et al., 2008; Caronni et al., 2011; Caronni et al., 2015). For this reason, an investigation on the effects of $C$. taylorii mucilage on native benthic communities exposed to other common stressors is strictly required.

In this paper, following a full-factorial design, nutrients were added to simulate eutrophication, macroalgae (both erect and crustose) were removed to simulate barrens produced by grazers and mucilage was manually removed to simulate mucilage-free conditions. We predict that the presence of mucilage would buffer the effect of nutrient enrichment on macroalgal abundance (antagonistic effect). On the contrary, mucilage would reasonably worsen the effects of herbivory, inhibiting macroalgal recovery after massive grazing events (total macroalgal removal) and enhancing the development of 
permanent barrens (synergistic effect). Therefore, the effect of mucilage was expected to be higher in non-enriched conditions especially when herbivores where present (Burkepile \& Hay, 2006; Guarnieri et al., 2014).

\section{MATERIAL AND METHODS Study site and experimental design}

The manipulative field experiment was conducted in Tavolara Punta Coda Cavallo Marine Protected Area (hereafter TPCC MPA, North-East Sardinia, Western Mediterranean), during the summer of 2014. Punta Don Diego Bay $\left(40^{\circ} 52^{\prime} 34.62^{\prime \prime} \mathrm{N} ; 9^{\circ} 39^{\prime} 21.19^{\prime \prime} \mathrm{E}\right)$, located in a partially protected zone of the MPA (traditional economic activities as fishing and recreation are allowed), was chosen for the experiment as $C$. taylorii blooms have been recurrently abundant there in the recent years (Caronni et al., 2014) (Fig. 1). The study area is characterized by oligotrophic waters $(\mathrm{P}: 0.006 \pm 0.0003 \mu \mathrm{M} ; \mathrm{N}: 0.3 \pm 0.008 \mu \mathrm{M})$ and a well-developed and diversified macroalgal community is present. The main grazers in the area are sea-urchins (Paracentrotus lividus; Lamarck, 1816), whose grazing may cause important changes in the distribution patterns of benthic communities, exerting a paramount role in the transition from macroalgal beds to barrens where only a few coralline algae are present (Boudouresque \& Verlaque, 2001; Hereu et al., 2004). Urchin density in the study area is of about 3.5 ind $\mathrm{m}^{-2}$ (P. Panzalis, pers. comm., 2013).

Two rocky areas of about $10 \mathrm{~m}^{2}$ (20 m apart), comparable in water motion, topography, and inclination of the rocky substrate, were randomly chosen in the bay at $1.5 \mathrm{~m}$ of depth (highest C. taylorii cell density depth, (Caronni et al., 2015). In each area 18 plots 20x20 cm in size were prepared and randomly assigned to one treatment.

The experimental design consisted of three factors: three grazing levels crossed with two nutrient enrichment and two mucilage removal treatments, following a factorial design, and three replicates for each combination of treatments were considered $(N=36)$. To obtain such treatments, plots were differently manipulated at the beginning of July: 1 . the mucilaginous aggregates were manually removed from half of the plots $(M-)$, while mucilage was maintained in the other half of them $(\mathrm{M}+)$; 2 . the substratum was scraped at three levels: total (G100\%: all the surface was fully scraped), partial (G50\%: the 50\% of the surface was fully scraped) and no (G0\%) removal of macroalgae (both erect and crustose) was conducted, using an iron brush to simulate the effect of grazers such as P. lividus, responsible for the formation of extended sea urchin barrens (Hereu, 2005); 3. nutrient enrichment was obtained in half of the plots, all in the same area, to avoid nutrient enrichment of control plots (E+vs E- refereed to enriched and non-enriched) $(N=36)$. For nutrient enrichment, small-mesh nylon bags ( $2 \mathrm{~mm}$ mesh size) filled with slow-release fertilizer pellets (Osmocote ${ }^{\circledR} ; 18: 9: 10, \mathrm{~N}: \mathrm{P}: \mathrm{K}$ ) were used, following Bulleri, Russell \& Connell (2012) and Guarnieri et al. (2014). The bags were fixed to a brick and positioned on the rocky bottom at the edge of each unit. Overall, $40 \mathrm{~g}$ of fertilizer were added in each plot, placing two bags with $20 \mathrm{~g}$ of pellet at two opposite sides of the plot. The amount of fertilizer in each bag was decided according to previous studies (Worm \& Sommer, 2000). To ensure enriched conditions throughout the experiment, nutrient bags were monthly replaced. 


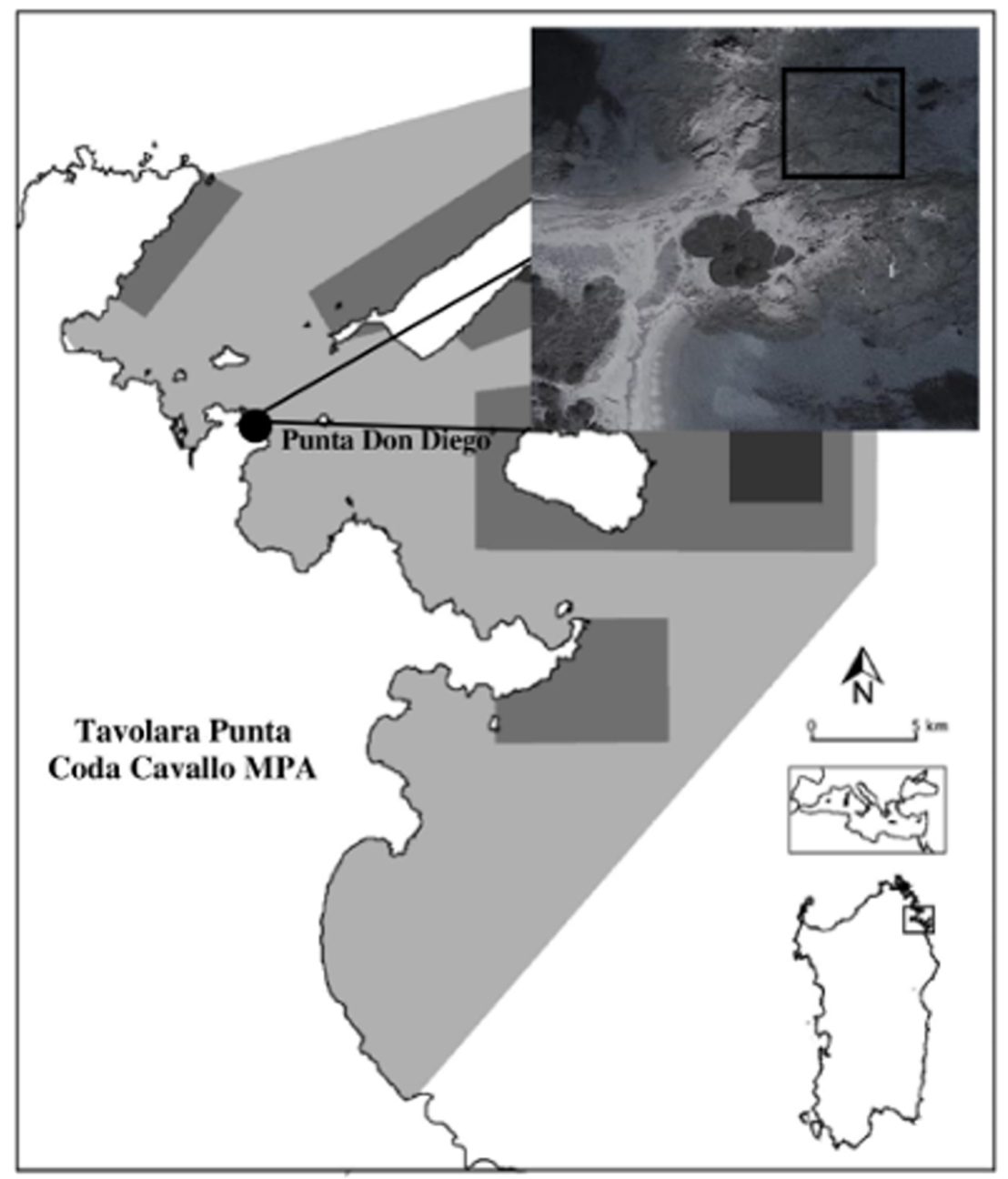

Figure 1 Localization of the study area in Tavolara Punta Coda Cavallo Marine Protected Area. The differently protected zones of the MPA are also indicated: light grey indicates $\mathrm{C}$ zones; middle grey B zones and dark grey A zones.

Full-size DOI: 10.7717/peerj.6908/fig-1

The concentration of nutrients ( $\mathrm{N}$ and $\mathrm{P}$ ) in the water was estimated two times from July to September 2014; 10 water samples $(125 \mathrm{ml})$ in each area were randomly taken in July $\left(S_{1}\right)$ and 4 weeks later, in August $\left(S_{2}\right)$. Samples were taken at approximately $10 \mathrm{~cm}$ from the bottom and at least $50 \mathrm{~cm}$ apart from nutrient bags. After collection, water samples were shaken, filtered $(0.45-\mu \mathrm{m}$ mesh size filter) and frozen, as suggested by Balata et al. (2010). They were transported to the University of Milan Bicocca, where concentrations of inorganic $\mathrm{N}$ and $\mathrm{P}$ (ammonia, nitrate, nitrite and phosphate) were estimated using a Spectrophotometer Lambda EZ201 Perkin Elmer (precision=0.3 nm). Chemical analyses of water samples confirmed that for both nutrients differences due to the enrichment were significant and consistent before and 4 weeks after the manipulation (Table 1).

After an initial sampling, performed at the beginning of July, before the manipulation, in each plot benthic assemblages were sampled two times; 8 weeks later (at the beginning of 
Table 1 Nutrient enrichment effectiveness. Mean nutrient (inorganic $\mathrm{N}$ and $\mathrm{P}$ ) concentration between nutrient addition and control plots (E+ and E-) on each sampling time.

\begin{tabular}{|c|c|c|c|c|c|c|c|}
\hline \multirow[t]{2}{*}{ Time } & \multirow[t]{2}{*}{ Treatment } & \multicolumn{3}{|c|}{ Inorganic $\mathbf{N}(\mu \mathbf{M})$} & \multicolumn{3}{|c|}{ Inorganic $\mathbf{P}(\mu \mathbf{M})$} \\
\hline & & $\begin{array}{l}\text { Mean } \\
(n=10)\end{array}$ & Stan. dev. & $t$-test $(\mathrm{P})$ & $\begin{array}{l}\text { Mean } \\
(n=10)\end{array}$ & Stan. dev. & $t$-test $(\mathrm{P})$ \\
\hline 8th week & $\mathrm{E}+$ & 0.720 & 0.00039 & \multirow{2}{*}{0.0001} & 0.170 & 0.00027 & \multirow{2}{*}{0.0003} \\
\hline 8th week & E- & 0.290 & 0.00035 & & 0.001 & 0.00013 & \\
\hline 36th week & $\mathrm{E}+$ & 0.780 & 0.00034 & \multirow{2}{*}{0.0002} & 0.190 & 0.00031 & \multirow{2}{*}{0.0001} \\
\hline 36th week & E- & 0.320 & 0.00021 & & 0.010 & 0.00021 & \\
\hline
\end{tabular}

September 2014, ) and 36 weeks later (in March 2015), to evaluate the short and long-term effects of the three stressors, respectively.

The assemblages in each plot were sampled photographically using a Nikon Coolpix AW130 underwater camera (16 Megapixel, Tokyo, Japan). The camera was held at a consistent distance from the substrate (approximately $50 \mathrm{~cm}$ ) as suggested by Jonker, Johns $\&$ Osborne (2008), paying attention to frame the entire experimental plot. Applying image analysis tools, the percent cover (\%) of each macroalgal taxon was assessed, superimposing a grid of twenty-five sub-quadrats onto each image, scoring each sub-quadrat from 0 to $4 \%$ and adding the 25 resulting values to obtain the total cover (Dethier et al., 1993).

\section{Statistical analyses}

A distance-based permutational multivariate analysis of variance (PERMANOVA) (Anderson, 2001) was performed using the software PERMANOVA (Anderson, 2005), to analyse the response of the macroalgal assemblage to experimental conditions across time. The analyses were based on Bray-Curtis dissimilarities calculated on non-transformed data. Each term in the analysis was tested using 9,999 random permutations. To test for short and long-term effects of treatments and to analyse independent data (Underwood, 1997), two PERMANOVAs were performed on data collected 8 and 36 weeks after the manipulation), respectively. The experimental design consisted of three factors: nutrient enrichment (two levels, fixed), grazing exclusion (three levels, fixed and orthogonal) and mucilage removal (two levels, fixed and orthogonal). Significant terms relevant to the hypotheses were investigated through post hoc pair-wise comparisons and a SIMPER test was also run (Primer v6) to point out the relative contribution of each taxon to the dissimilarities observed among treatments (Clarke, 1993). Finally, a non-metric multidimensional scaling (nMDS) was used for the graphical ordination of data.

To investigate the differences among treatments evidenced by the SIMPER test for the main macroalgal taxa, a three-way ANOVA was also run for each taxon abundance using the software GMAV5 (University of Sydney, Australia). Cochran's test was run prior to each ANOVA to test for homogeneity of variances and normality was assured by Kolmogorov-Smirnov test. Student-Newman-Keuls (SNK) tests were used for a posteriori comparison of means (Underwood, 1997). 


\begin{tabular}{|c|c|c|c|c|c|}
\hline Source of variation & $d f$ & SS & MS & $F$ & $P$ (perm.) \\
\hline Nutrient enrichment $(E)$ & 1 & $1,538.0381$ & $1,538.0381$ & 23.3065 & 0.0001 \\
\hline Grazing exclusion $(G)$ & 2 & $3,080.7599$ & $1,540.3799$ & 23.3420 & 0.0001 \\
\hline Mucilage removal $(M)$ & 1 & 246.5692 & 246.5692 & 3.7364 & 0.0348 \\
\hline$E \times G$ & 2 & $1,428.6083$ & 714.3041 & 10.8241 & 0.0001 \\
\hline$E \times M$ & 1 & 192.8727 & 192.8727 & 2.9227 & 0.0656 \\
\hline$G \times M$ & 2 & 292.5294 & 146.2647 & 2.2164 & 0.0824 \\
\hline$E \times G \times M$ & 2 & 286.0645 & 143.0322 & 2.1674 & 0.0472 \\
\hline Residual & 24 & $1,583.8026$ & 65.9918 & & \\
\hline Total & 35 & $8,649.2446$ & & & \\
\hline
\end{tabular}

\section{RESULTS}

\section{Short-term macroalgal response to disturbance}

At the end of the experiment, 8 weeks after the manipulation, eight macroalgal taxa/morphological groups were found: Acetabularia acetabulum (L.) Silva., Dark filamentous algae (DFA), Dasycladus vermicularis (Scopoli) Krasser, Crustose coralline algae (CCA), Dictyota spp. Laurencia spp., Liagora spp., and Padina pavonica (L.) Thivy. The combination of three analyzed stressors affected the short-term recovery of assemblages (PERMANOVA significant $\mathrm{E} \times \mathrm{G} \times \mathrm{M}$ interaction, Table 2). Pair-wise comparisons showed statistically significant differences between enriched and non-enriched plots only when the other two stressors were absent or when their effect was poor (M-G0\% and M-G50\%). Furthermore, in non-enriched conditions statistically significant differences due to mucilage were recorded, especially in plots where the grazing pressure was high $(\mathrm{E}-\mathrm{M}+\mathrm{G} 100 \% ; \neq \mathrm{E}-\mathrm{M}-\mathrm{G} 100 \%)$. On the contrary, the same effect was not observed in enriched plots. Additionally, the effect of mucilage was not detected where the grazing pressure was null or low, in both enriched and non-enriched plots (E+G0\% and E-G0\%), as clearly depicted in the nMDS graphs (Fig. 2).

Differences in the composition of macroalgal assemblages were found to be related to all three considered stressors and the Simper test evidenced that four taxa remarkably contributed to the observed dissimilarities: dark filamentous algae, crustose coralline algae, Dictyota spp. and Laurencia spp.

Finally, all the ANOVAs performed on these taxa (DFA, CCA, Dictyota spp. and Laurencia spp.) detected differences for the $\mathrm{E} \times \mathrm{G} \times \mathrm{M}$ interaction term (Tables 3 and 4; Fig. 3). Particularly, dark filamentous algae seemed to be more abundant in enriched plots, especially where mucilage and macroalgae had been removed (E+M-G100\%), while a higher percent cover of crustose coralline algae was observed where nutrients had been increased especially if the grazing pressure was null, independently from mucilage presence (E+M-G0\% and E+M+G0\%). Finally, both the erect species (Dictyota spp. and Laurencia 

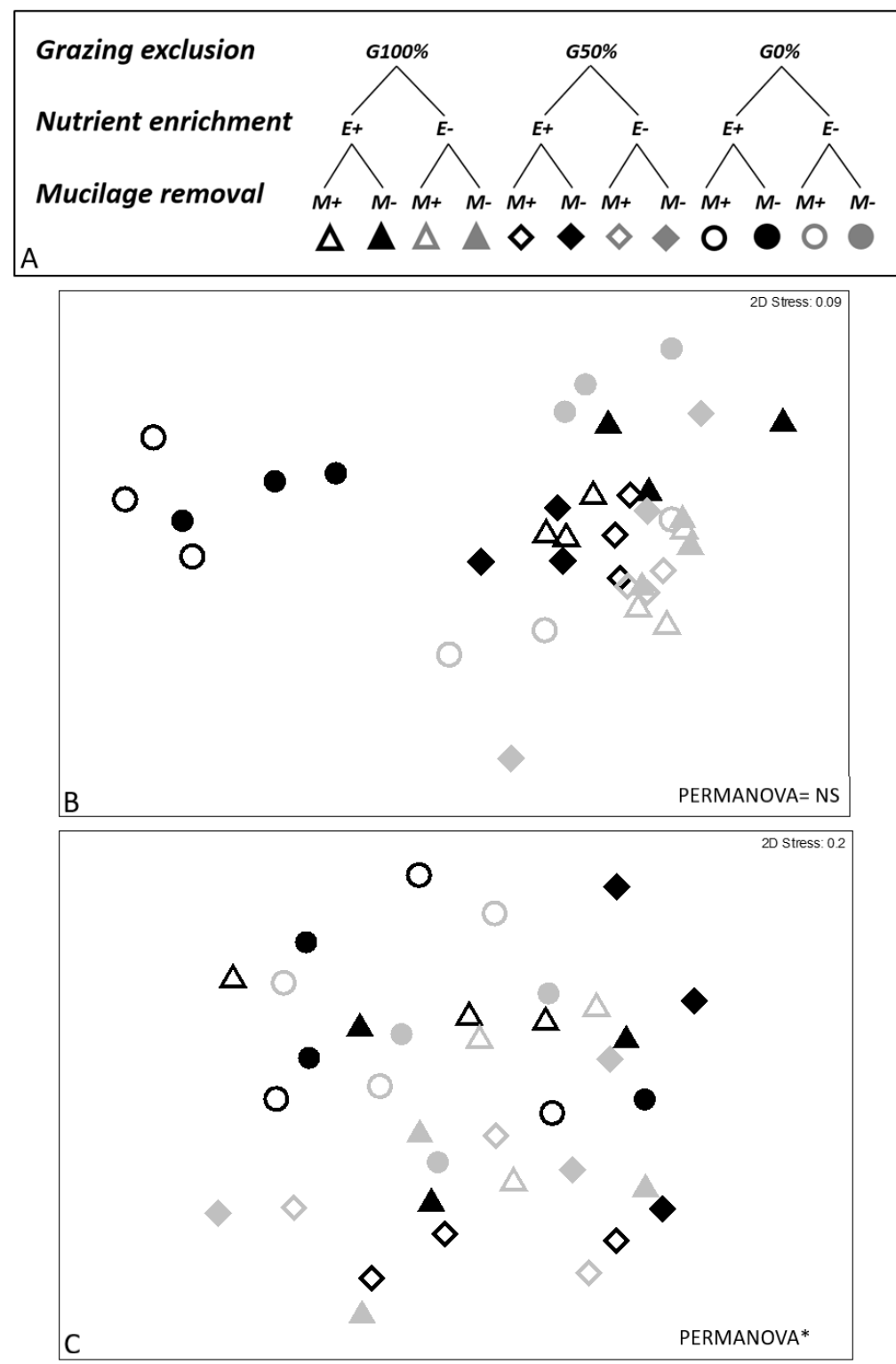

Figure 2 Experimental design and nMDS. In the experimental design (A) three grazing levels were considered (G100\%, G50\% and G0\% referred to total, partial and no removal of macroalgae; for nutrient enrichment two levels were considered (E+ vs E- referred to enriched and non-enriched) as well as for mucilage (M+ vs M- referred to plots with and without mucilage). nMDS was performed on short- (8th week, B) and long-term (36th week, C) data. nMDS ordination was not significant on short-term.

Full-size DOI: 10.7717/peerj.6908/fig-2

spp.) were more abundant in enriched plots, where the grazing pressure was null or low and mucilage had been removed (E+M-G0\% and E+M-G50\%) (Tables 3 and 4; Fig. 3).

\section{Long-term macroalgal response to disturbance}

Thirty-six weeks after the manipulation only six macroalgal taxa/groups were overall found and the effect of treatments (nutrient enrichment, grazing exclusion and mucilage 
Table 3 ANOVA results. Results of ANOVAs on the effect of each treatment (nutrient enrichment (E), grazing exclusion (G) and mucilage removal (M) on the percent cover of DFA, CCA, Dictyota spp. and Laurencia spp. at short-term (8 weeks). Significant P-values are given in bold.

\begin{tabular}{|c|c|c|c|c|c|c|c|c|c|}
\hline \multirow[t]{2}{*}{ Source of variation } & \multirow[b]{2}{*}{$d f$} & \multicolumn{2}{|c|}{ DFA } & \multicolumn{2}{|c|}{ CCA } & \multicolumn{2}{|c|}{ Dictyotales } & \multicolumn{2}{|c|}{ Laurencia spp. } \\
\hline & & $F$ & $P$ & $F$ & $P$ & $F$ & $P$ & $F$ & $P$ \\
\hline Nutrient enrichment $(E)$ & 1 & 5.68 & 0.0254 & 69.84 & 0.0000 & 0.52 & 0.0471 & 67.83 & 0.0000 \\
\hline Grazing exclusion $(G)$ & 2 & 2.24 & 0.0388 & 32.29 & 0.0000 & 37.10 & 0.0000 & 48.23 & 0.0000 \\
\hline Mucilage removal $(M)$ & 1 & 7.36 & 0.0122 & 1.92 & 0.0383 & 0.12 & 0.0252 & 0.25 & 0.0213 \\
\hline$E \times G$ & 2 & 9.06 & 0.0012 & 8.52 & 0.0016 & 9.60 & 0.0009 & 22.80 & 0.0000 \\
\hline$E \times M$ & 1 & 9.06 & 0.0012 & 0.32 & 0.5792 & 0.01 & 0.9102 & 8.75 & 0.0069 \\
\hline$G \times M$ & 2 & 3.47 & 0.0473 & 3.62 & 0.0424 & 0.45 & 0.6451 & 0.54 & 0.5918 \\
\hline$E \times G \times M$ & 2 & 1.88 & 0.0487 & 2.71 & 0.0469 & 0.12 & 0.0490 & 1.37 & 0.0373 \\
\hline Residual & 24 & & & & & & & & \\
\hline Total & 35 & & & & & & & & \\
\hline Cochran's test $(C)$ & & \multicolumn{2}{|c|}{$0.3556(\mathrm{NS})$} & \multicolumn{2}{|c|}{$0.3542(\mathrm{NS})$} & \multicolumn{2}{|c|}{0.3453 (NS) } & \multicolumn{2}{|c|}{0.3996 (NS) } \\
\hline
\end{tabular}

removal) was neither highlighted on the most abundant algae (DFA, CCA, Dictyota spp., Laurencia spp. and P. pavonica) nor on the whole structure of the macroalgal assemblages, as graphically evidenced also by the nMDS ordination (Fig. 2).

\section{DISCUSSION}

An interactive effect of the three stressors on the short-term recovery (8 weeks after the manipulation) of the considered macroalgal assemblages was highlighted in the study (Figs. 2 and 3; Tables 3 and 4). Significant differences in the composition and abundance of macroalgae were observed depending on enrichment, but only when mucilage and grazing were absent (Figs. 2 and 3; Tables 3 and 4). These results are in accordance with those of other studies investigating the role of nutrient enrichment in determining macroalgal abundance (e.g., McGlathery, 2001; Teichberg et al., 2008; Sotka \& Hay, 2009) and confirm that, when nutrient enrichment is the only stressor, it leads to a remarkable increase of total macroalgal biomass. More in detail, a positive response to nutrient enrichment of the different macroalgal taxa present in the study area was observed, with an enhancing effect on both turf-forming and erect macroalgae. Our evidence supports the results obtained by Bulleri, Russell \& Connell (2012) who found a positive effect of enrichment on all macroalgae, contrarily to Pedersen \& Borum (1996), who observed an enhancement of turf-forming algae, in particular of DFA.

Instead, no relevant differences were observed in the composition of macroalgal assemblages exposed to nutrient enrichment when one of the other two stressors was present (Figs. 2 and 3; Tables 3 and 4). In particular, a buffering effect of mucilage on nutrient enrichment was recorded. In plots where mucilage was present, no significant differences in macroalgal assemblages' abundance and composition were noticed between enriched and non-enriched treatments (Figs. 2 and 3; Tables 3 and 4). Results can be explained by considering that microalgae take up nutrients faster than macroalgae and consequently mucilage might be responsible for the sequestration of large amounts of nutrients from the water column, elements then used by microalgae embedded in aggregates to survive and 
Table 4 SNK results. Results of SNK test on ExGxM interaction for the 4 main taxa for: nutrient enrichment (E+ vs E-), grazing exclusion (G100\%, G50\% and G0\%) and mucilage removal (M+ vs M-).

\begin{tabular}{|c|c|c|}
\hline $\begin{array}{l}\text { DFA } \\
\text { Grazing exclusion } \\
\text { M+ } \\
\text { E+ G100\%>G50\%=G0\% } \\
\text { E- G100\%=G50\%=G0\% } \\
\text { M- } \\
\text { E+ G100\%>G50\%>G0\% } \\
\text { E- G100\%=G50\%>G0\% }\end{array}$ & $\begin{array}{l}\text { Mucilage removal } \\
\text { G100\% } \\
\text { E+ M+<M- } \\
\text { E- M+=M- } \\
\text { G50\% } \\
\text { E+ M+=M- } \\
\text { E- M+=M- } \\
\text { G0\% } \\
\text { E+ M+=M- } \\
\text { E- M+=M- }\end{array}$ & $\begin{array}{l}\text { Nutrient enrichment } \\
\text { G100\% } \\
\text { M+E+=E- } \\
\text { M- E+>E- } \\
\text { G50\% } \\
\text { M+E+=E- } \\
\text { M- E+>E- } \\
\text { G0\% } \\
\text { M+E+=E- } \\
\text { M- E+=E- }\end{array}$ \\
\hline $\begin{array}{l}\text { CCA } \\
\text { Grazing exclusion } \\
\text { M+ } \\
\text { E+ G100\%<G50\%<G0\% } \\
\text { E- G100\%=G50\%=G0\% } \\
\text { M- } \\
\text { E+ G100\%<G50\%<G0\% } \\
\text { E- G100\%=G50\%=G0\% }\end{array}$ & $\begin{array}{l}\text { Mucilage removal } \\
\text { G100\% } \\
\text { E+ M+=M- } \\
\text { E- M+=M- } \\
\text { G50\% } \\
\text { E+ M+=M- } \\
\text { E- M+=M- } \\
\text { G0\% } \\
\text { E+ M+<M- } \\
\text { E- M+=M- }\end{array}$ & $\begin{array}{l}\text { Nutrient enrichment } \\
\text { G100\% } \\
\text { M+E+=E- } \\
\text { M- E+=E- } \\
\text { G50\% } \\
\text { M+E+=E- } \\
\text { M- E+=E- } \\
\text { G0\% } \\
\text { M+E+>E- } \\
\text { M- E+>E- }\end{array}$ \\
\hline $\begin{array}{l}\text { Dictyotales } \\
\text { Grazing exclusion } \\
\text { M+ } \\
\text { E+ G100\%=G50\%=G0\% } \\
\text { E- G100\%=G50\%=G0\% } \\
\text { M- } \\
\text { E+ G100\%<G50\%=G0\% } \\
\text { E- G100\%=G50\%=G0\% }\end{array}$ & $\begin{array}{l}\text { Mucilage removal } \\
\text { G100\% } \\
\text { E+ M+=M- } \\
\text { E- M+=M- } \\
\text { G50\% } \\
\text { E+ M+<M- } \\
\text { E- M+=M- } \\
\text { G0\% } \\
\text { E+ M+<M- } \\
\text { E- M+=M- }\end{array}$ & $\begin{array}{l}\text { Nutrient enrichment } \\
\text { G100\% } \\
\text { M+E+=E- } \\
\text { M- E+=E- } \\
\text { G50\% } \\
\text { M+E+=E- } \\
\text { M- E+>E- } \\
\text { G0\% } \\
\text { M+E+=E- } \\
\text { M- E+>E- }\end{array}$ \\
\hline $\begin{array}{l}\text { Laurencia spp. } \\
\text { Grazing exclusion } \\
\text { M+ } \\
\text { E+ }+\mathrm{G} 100 \%=\mathrm{G} 50 \%=\mathrm{G} 0 \% \\
\text { E- } \mathrm{G} 100 \%=\mathrm{G} 50 \%=\mathrm{G} 0 \% \\
\text { M- } \\
\text { E+ } \mathrm{G} 100 \%<\mathrm{G} 50 \%=\mathrm{G} 0 \% \\
\text { E- G100\%=G50\%=G0\% }\end{array}$ & $\begin{array}{l}\text { Mucilage removal } \\
\text { G100\% } \\
\text { E+ M+=M- } \\
\text { E- M+=M- } \\
\text { G50\% } \\
\text { E+ M+<M- } \\
\text { E- M+=M- } \\
\text { G0\% } \\
\text { E+ M+<M- } \\
\text { E- M+=M- }\end{array}$ & $\begin{array}{l}\text { Nutrient enrichment } \\
\text { G100\% } \\
\text { M+E+=E- } \\
\text { M- E+=E- } \\
\text { G50\% } \\
\text { M+E+=E- } \\
\text { M- E+>E- } \\
\text { G0\% } \\
\text { M+E+=E- } \\
\text { M- E+>E- }\end{array}$ \\
\hline
\end{tabular}

proliferate (Reynolds, 2007). As a matter of fact, aggregates are biota-rich environments where the concentration of nutrients can be dramatically higher than in the surrounding seawater (Del Negro et al., 2005). For this reason, it is plausible that, in plots with mucilage, only a small amount of total nutrients released in the water was available for macroalgae as a conspicuous portion of them was sequestrated and used by mucilage. Furthermore, even if Huang \& Boney (1983) observed that, in laboratory conditions, the growth of some species of green and brown algae was enhanced by diatoms mucilage, mucilaginous aggregates are generally known to overgrow macroalgae causing their mechanical suffocation and 

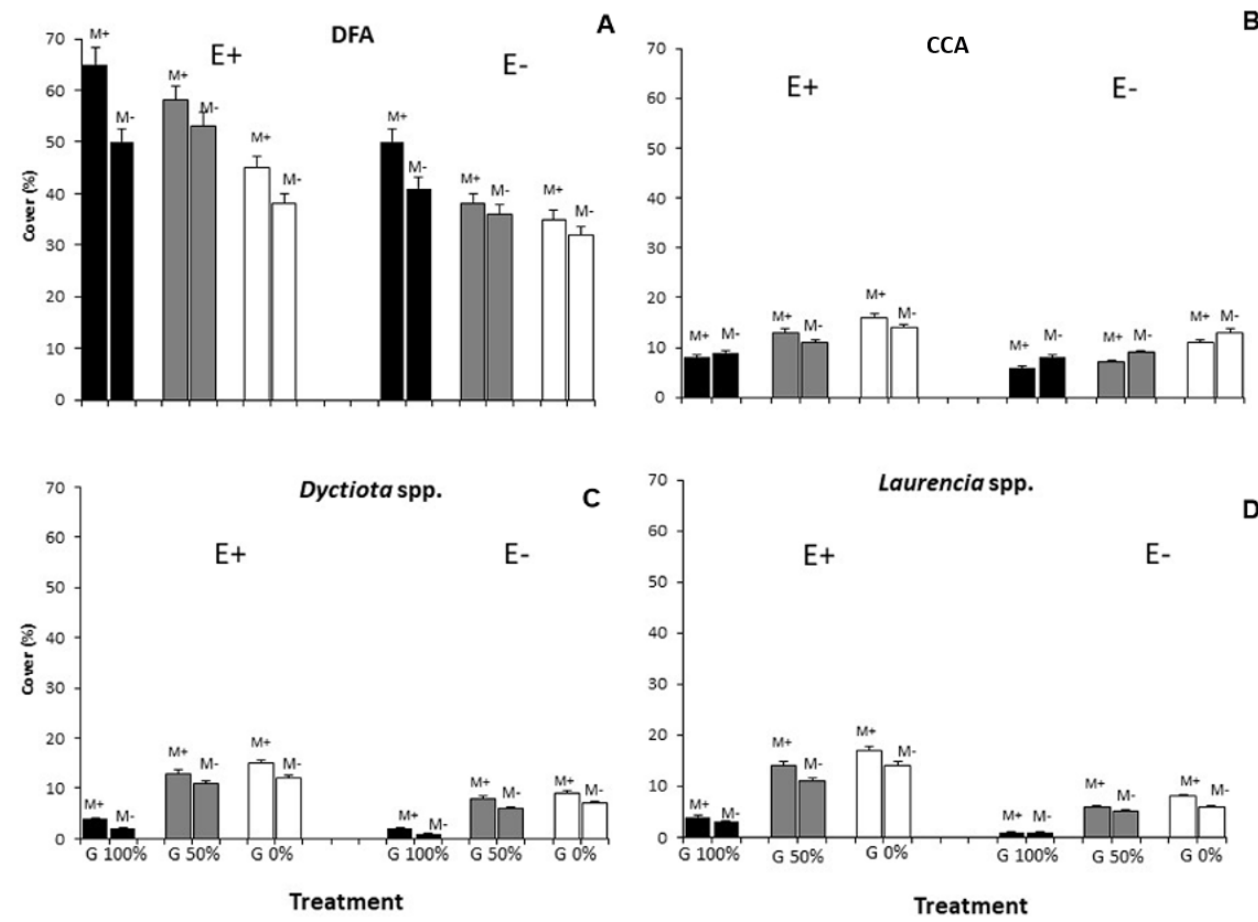

8 weeks after the manipulation

Figure 3 Main taxa percent cover. Percent cover (mean $\% \pm \mathrm{SE}, n=20$ ) of the 4 main taxa (dark filamentous algae (DFA), crustose coralline algae (CCA), Dictyota spp. and Laurencia spp.) for each combination of treatments: nutrient enrichment (E+ and E-); grazing (100\%, 50\% and $0 \%$ of macroalgal removal); mucilage ( $\mathrm{M}+$ and $\mathrm{M}-)$ ).

Full-size DOI: $10.7717 /$ peerj.6908/fig-3

rapid biomass depletion (Misic, Schiaparelli \& Covazzi Harriague, 2011). Moreover, Müller et al. (1998) assumed that all benthic organisms are seriously damaged by mucilage aggregates, even if their cover is thin because they usually release toxins directly affecting cell metabolism. Therefore, when mucilage and nutrient enrichment acted simultaneously, the expected increase in macroalgal abundance due to nutrient enrichment could have been counterbalanced by the presence of mucilage on the substratum.

The positive effect of nutrient enrichment did not seem buffered by mucilage; only considering crustose coralline algae, their abundance was equal in all enriched plots, independently from the presence of mucilage (Figs. 2 and 3; Tables 3 and 4). Schiaparelli et al. (2007) and Figueiredo \& Steneck (2000) suggested that coralline algae could be seriously damaged by mucilage (especially when its presence on the substratum lasted for a long time), but our results mostly agree with Bulleri (2006) who evidenced their ability to survive for long periods if overgrown by other species.

As for mucilage, also the effect of grazing seemed to buffer that of nutrient enrichment (Figs. 2 and 3; Tables 3 and 4). About this, Guarnieri et al. (2014) observed a relatively constant macroalgal cover, also in nutrient enriched conditions, when a high grazing pressure acted. Our results highlight that the presence of herbivores can strongly affect the proliferation of macroalgae, lowering the positive effect of enrichment. Therefore, even if 
the results of several previous experiments suggested that both increased nutrient loading and reduced grazer densities favour an intense macroalgal growth (e.g., Geertz-Hansen et al., 1993; Hauxwell et al., 1998; Lotze \& Worm, 2000), the reduction of herbivory often seems to be the main factor triggering the restoration process of macroalgal assemblages after disturbance (Scheffer et al., 2001), and the role of nutrient enrichment appears to be only secondary. Nevertheless, herbivory does not represent the exclusive process in structuring macroalgal assemblages, as our results highlight its interactive effect with nutrient availability in mediating the outcomes of grazing pressure, similarly to Burkepile \& Hay (2006). In this interaction, the mucilage plays a relevant role that should not be neglected. In fact, where the grazing pressure was null or low the presence of mucilage did not influence the abundance of the main taxa (Figs. 2 and 3; Tables 3 and 4) except for where enrichment was done. This suggests a primary role of herbivores and nutrients in regulating the abundance of macroalgae (Lawrence, 1975; Underwood, 1980; Scheibling, 1986; Geertz-Hansen et al., 1993). However, mucilage effect is corroborated by the effect of enrichment on Laurencia spp. and Dictyotales, at no grazing pressure, only where the mucilage was removed. This would support the hypothesis that the effect of enhancement produced by nutrient enrichment can only be conspicuous where the negative effect of mucilage was nullified.

Therefore, the effect of mucilage seems to be significantly detrimental only where communities are stressed by high densities of herbivores and nutrients are not so abundant to remarkably increase macroalgal biomass. In such conditions, indeed, damages caused by both mucilage suffocation and mechanical detachment of macroalgae (especially of erect and frondose species) (Schiaparelli et al., 2007; Lugliè et al., 2008) are not worsened by grazing pressure and balanced by nutrient enrichment. Also, the lower abundance of erect species such as Dictyotales and Laurencia spp. confirms that the erect species are more damaged by mucilage than the turf-forming ones. Furthermore, turf-forming species appeared to be more abundant also where macroalgae were removed because, in such conditions, a wider free space was available. Furthermore, in this last case, lower competition favoured the development of opportunistic species such as turf-forming macroalgae (Bulleri, Russell \& Connell, 2012).

Finally, the lack of effects of the three considered stressors observed after about eight months of study deserves a deeper insight. Whether the change through time of effects was biased by a seasonal effect (because of the variable phenology of algal taxa) it will remain unknown because unfortunately no data are available at present. Therefore, very hard disentangling mechanisms (seasonal effect vs lack of complete recover) are responsible for the lack of persistent differences through time. However, even if the variability of effects through the year could occur depending on the composing species seasonal performance, there are reasons to hypothesize that the macroalgal assemblage would cope with the considered stressors assisted by cyclical responses.

\section{CONCLUSIONS}

The short-term effect ( 8 weeks) of the considered multiple stressors on the macroalgal community suggest the mucilage and grazing to be antagonistic to nutrient enrichment, 
while mucilage presence and herbivore pressure seem to act synergistically. Particularly, dark filamentous algae were more abundant in enriched plots, especially where mucilage and macroalgae had been removed; conversely, a higher cover of crustose coralline algae was observed where nutrients had been increased and no grazing pressure acted. Furthermore, the abundance of Dictyota spp. and Laurencia spp. was significantly higher in enriched mucilage-free plots where the grazing pressure was null or low.

However, effects of treatments on the overall assemblage of the macroalgal community were not persistent on the longer-term (36 weeks after the manipulation) and this indicates the capacity of a shallow-water macroalgal community to quickly recover from these simultaneous impacts. Therefore, even if these results substantially confirm the predictions on the interactive stressors (mucilage would have buffered the effect of nutrient enrichment, worsened the one of herbivory and that a greater effect of mucilage would have been observed in non-enriched conditions especially when herbivores were present), the rapid fading of their effects in a few months makes it not strictly necessary or urgent to lay out guidelines for managers.

At the same time, the results of this study can also help to forecast areas where nutrient pollution will have more detrimental effects on macroalgal assemblages, basing on the grazers density and the frequency of mucilaginous blooms. Furthermore, some interesting ecological lessons can also be gained, as relevant information has been provided about the resilience of macroalgal communities to mucilage effects at non-pristine conditions, which concerns the nutrient water status and the herbivores control by predators. In such conditions indeed the effects of disturbances, even when they are due by multiple stressors acting together, may be more efficiently buffered within the system (consistently to Agardy (1994) and to Jentoft, Van Son \& Bjørkan (2007)), highlighting that stability of the state would be provided by other feed-back mechanisms.

\section{ACKNOWLEDGEMENTS}

We thank the two anonymous referees and the editor Craig Nelson for providing useful suggestions to improve the ms. Furthermore, we thank Luisa Polastro, Sidney Freedman and Nadia Carlier for the English revision, Luigi Piazzi for the fundamental help in data analysis and Matteo Grechi and Gianluca Cavagna for the precious help during image analysis.

\section{ADDITIONAL INFORMATION AND DECLARATIONS}

\section{Funding}

This work was supported by L'Oréal-Unesco, which funded Sarah Caronni with a L'OréalUnesco for Women in Science Fellowship Grant. The funders had no role in study design, data collection and analysis, decision to publish, or preparation of the manuscript.

\section{Grant Disclosures}

The following grant information was disclosed by the authors:

Sarah Caronni with a L'Oréal-Unesco for Women in Science Fellowship Grant. 


\section{Competing Interests}

The authors declare there are no competing interests.

\section{Author Contributions}

- Sarah Caronni conceived and designed the experiments, performed the experiments, analyzed the data, prepared figures and/or tables, authored or reviewed drafts of the paper, approved the final draft.

- Chiara Calabretti, Maria Anna Delaria and Giovanni Macri performed the experiments, approved the final draft.

- Sandra Citterio contributed reagents/materials/analysis tools, authored or reviewed drafts of the paper, approved the final draft.

- Rodolfo Gentili prepared figures and/or tables, approved the final draft.

- Chiara Montagnani authored or reviewed drafts of the paper, approved the final draft, enghish editing post suggestions of the professional language editing service of our university.

- Augusto Navone and Pieraugusto Panzalis contributed reagents/materials/analysis tools, approved the final draft.

- Giulia Piazza contributed reagents/materials/analysis tools, prepared figures and/or tables, revision.

- Giulia Ceccherelli conceived and designed the experiments, performed the experiments, analyzed the data, contributed reagents/materials/analysis tools, authored or reviewed drafts of the paper, approved the final draft.

\section{Data Availability}

The following information was supplied regarding data availability:

The raw data are available in a Supplemental File.

\section{Supplemental Information}

Supplemental information for this article can be found online at http://dx.doi.org/10.7717/ peerj.6908\#supplemental-information.

\section{REFERENCES}

Adams SM. 2005. Assessing cause and effect of multiple stressors on marine systems. Marine Pollution Bulletin 51(8-12):649-657 DOI 10.1016/j.marpolbul.2004.11.040.

Agardy MT. 1994. Advances in marine conservation: the role of marine protected areas. Trends in Ecology \& Evolution 9(7):267-270 DOI 10.1016/0169-5347(94)90297-6.

Anderson DM, Glibert PM, Burkholder JM. 2002. Harmful algal blooms and eutrophication: nutrient sources, composition and consequences. Estuaries 25(4):562-584 DOI 10.1007/BF02804901.

Anderson MJ. 2001. A new method for non-parametric multivariate analysis of variance. Austral Ecology 26(1):32-46 DOI 10.1111/j.1442-9993.2001.01070.pp.x.

Anderson MJ. 2005. Permutation ANOVA: a FORTRAN computer program for permutational multivariate analysis of variance. Auckland: Department of Statistics, University of Auckland, 24. 
Arévalo R, Pinedo S, Ballesteros E. 2007. Changes in the composition and structure of Mediterranean rocky-shore communities following a gradient of nutrient enrichment: descriptive study and test of proposed methods to assess water quality regarding macroalgae. Marine Pollution Bulletin 55(1-6):104-113 DOI 10.1016/j.marpolbul.2006.08.023.

Armitage AR, Frankovich TA, HeckJames KL, Fourqurean W. 2005. Experimental nutrient enrichment causes complex changes in seagrass, microalgae, and macroalgae community structure in Florida Bay. Estuaries and Coasts 28(3):422-438 DOI 10.1007/BF02693924.

Balata D, Piazzi L, Nesti U, Bulleri F, Bertocci I. 2010. Effects of enhanced loads of nutrients on epiphytes on leaves and rhizomes of Posidonia oceanica. Journal of Sea Research 63(3-4):173-179 DOI 10.1016/j.seares.2009.12.001.

Boada J, Arthur R, Alonso D, Pagès JF, Pessarrodona A, Oliva S, Ceccherelli G, Piazzi L, Romero J, Alcoverro T. 2017. Immanent conditions determine imminent collapses: nutrient regimes define the resilience of macroalgal communities. Proceedings of the Royal Society B: Biological Sciences 284(1851):20162814 DOI 10.1098/rspb.2016.2814.

Boudouresque CF, Verlaque M. 2001. Ecology of Paracentrotus lividus. Developments in Aquaculture and Fisheries Science 32:177-216 DOI 10.1016/S0167-9309(01)80013-2.

Bulleri F. 2006. Duration of overgrowth affects survival of encrusting coralline algae. Marine Ecology Progress Series 321:79-85 DOI 10.3354/meps321079.

Bulleri F, Russell BD, Connell SD. 2012. Context-dependency in the effects of nutrient loading and consumers on the availability of space in marine rocky environments. PLOS ONE 7(3):e33825 DOI 10.1371/journal.pone.0033825.

Burkepile DE, Hay ME. 2006. Herbivore vs. nutrient control of marine primary producers: context-dependent effects. Ecology 87(12):3128-3139 DOI 10.1890/0012-9658(2006)87[3128:HVNCOM]2.0.CO;2.

Caronni S, Bresciani A, Delaria MA, Meloni F, Navone A, Panzalis P, Heimann K, Ceccherelli G. 2015. Ecology of the benthic mucilage-forming microalga Chrysophaeum taylorii in the W Mediterranean Sea: substratum and depth preferences. Estuarine, Coastal and Shelf Science 161:38-45 DOI 10.1016/j.ecss.2015.04.012.

Caronni S, Ceccherelli G, Navone A, Panzalis P, Pinna S, Sechi N. 2011. I popolamenti bentonici nell'Area Marina Protetta Tavolara Punta Coda Cavallo (Sardegna nordorientale) dopo una fioritura della microalga Chrysophaeum taylorii Lewis \& Brian. Studi Trentini Sci Naturali Acta Geologica 89:107-110.

Caronni S, Delaria MA, Navone A, Panzalis P, Sechi N, Ceccherelli G. 2014. Relevant scales of variability of the benthic allochthonous microalga Chrysophaeum taylorii. Marine Biology 161(8):1787-1798 DOI 10.1007/s00227-014-2461-3.

Clarke KR. 1993. Non-parametric multivariate analyses of changes in community structure. Australian Journal of Ecology 18(1):117-143

DOI 10.1111/j.1442-9993.1993.tb00438.x.

Claudet J, Fraschetti S. 2010. Human-driven impacts on marine habitats: a regional meta-analysis in the Mediterranean Sea. Biological Conservation 143(9):2195-2206 DOI 10.1016/j.biocon.2010.06.004. 
Crain CM, Halpern BS, Beck MW, Kappel CV. 2009. Understanding and managing human threats to the coastal marine environment. Ecology and Conservation Biology 1162(1):39-62 DOI 10.1111/j.1749-6632.2009.04496.x.

Crain CM, Kroeker K, Halpern BS. 2008. Interactive and cumulative effects of multiple human stressors in marine systems. Ecology Letters 11(12):1304-1315 DOI 10.1111/j.1461-0248.2008.01253.x.

Del Negro P, Crevatin E, Larato C, Ferrari C, Totti C, Pompei M, Giani M, Berto D, Fonda Umani S. 2005. Mucilage microcosms. Science of the Total Environment 353(1-3):258-269 DOI 10.1016/j.scitotenv.2005.09.018.

Dethier MN, Graham ES, Cohen S, Tera LM. 1993. Visual versus random-point percent cover estimations: objective is not always better. Marine Ecology Progress Series 96:93-100 DOI 10.3354/meps096093.

Devescovi M, Iveša L. 2007. Short term impact of planktonic mucilage aggregates on macrobenthos along the Istrian rocky coast (Northern Adriatic, Croatia). Marine Pollution Bulletin 54(7):887-893 DOI 10.1016/j.marpolbul.2007.03.009.

Figueiredo MA d O, Steneck RS. 2000. Floristic and ecological studies of crustose coralline algae on Brazil's Abrolhos reefs. Proceedings of the 9th International Coral Reef Symposium 1:493-498.

Filbee-Dexter K, Scheibling RE. 2014. Sea urchin barrens as alternative stable states of collapsed kelp ecosystems. Marine Ecology 495:1-25 DOI 10.3354/meps10573.

Folt CL, Chen CY, Moore MV, Burnaford J. 1999. Synergism and antagonism among multiple stressors. Limnology and Oceanography 44(3part2):864-877 DOI 10.4319/lo.1999.44.3_part_2.0864.

Geertz-Hansen O, Sand-Jensen K, Hansen DF, Christiansen A. 1993. Growth and grazing control of abundance of the marine macroalga, Ulva lactuca L. in a eutrophic Danish estuary. Aquatic Botany 46(2):101-109 DOI 10.1016/0304-3770(93)90039-Y.

Graham MH. 2004. Effects of local deforestation on the diversity and structure of southern california giant kelp forest food webs. Ecosystem 7(4):341-357.

Guarnieri G, Bevilacqua S, Vignes F, Fraschetti S. 2014. Grazer removal and nutrient enrichment as recovery enhancers for overexploited rocky subtidal habitats. Oecologia 175(3):959-970 DOI 10.1007/s00442-014-2944-4.

Guidetti P, Fraschetti S, Terlizzi A, Boero F. 2003. Distribution patterns of sea urchins and barrens in shallow Mediterranean rocky reefs impacted by the illegal fishery of the rock-boring mollusc Lithophaga lithophaga. Marine Biology 143(6):1135-1142 DOI 10.1007/s00227-003-1163-z.

Hauxwell J, Mcclelland J, Behr PJ, Valiela I. 1998. Relative biomass importance of grazing and nutrient controls of macroalgal in three temperate shallow estuaries. Estuaries 21(2):347-360 DOI 10.2307/1352481.

Hecky RE, Kilham P. 1988. Nutrient limitation of phytoplankton in freshwater and marine environments: a review of recent evidence on the effects of enrichment. Limnology and Oceanographhy 33(4part2):796-822 DOI 10.4319/lo.1988.33.4part2.0796. 
Hereu B. 2005. Movement patterns of the sea urchin Paracentrotus lividus in a marine reserve and an unprotected area in the NW Mediterranean. Marine Ecology 26(1):54-62 DOI 10.1111/j.1439-0485.2005.00038.x.

Hereu B, Zabala M, Linares C, Sala E. 2004. Temporal and spatial variability in settlement of the sea urchin Paracentrotus lividus in the NW Mediterranean. Marine Biology 144(5):1011-1018 DOI 10.1007/s00227-003-1266-6.

Huang R, Boney AD. 1983. Effects of diatom mucilage on the growth and morphology of marine algae. Journal of Experimental Marine Biology and Ecology 67(1):79-89 DOI 10.1016/0022-0981(83)90136-3.

Jackson MC, Loewen CJG, Vinebrooke RD, Chimimba CT. 2016. Net effects of multiple stressors in freshwater ecosystems: a meta-analysis. Global Change Biology 22(1):180-189 DOI 10.1111/gcb.13028.

Jentoft S, Van Son TC, Bjørkan M. 2007. Marine protected areas: a governance system analysis. Human Ecology 35(5):611-622 DOI 10.1007/s10745-007-9125-6.

Jonker MM, Johns KK, Osborne KK. 2008. Surveys of benthic reef communities using underwater digital photography and counts of juvenile corals. Long-term monitoring of the great barrier reef. Standard Operational Procedure. No. 10. Cape Ferguson: Australian Institute of Marine Science, 75 p.

Karez R, Engelbert S, Kraufvelin P, Pedersen MF, Sommer U. 2004. Biomass response and changes in composition of ephemeral macroalgal assemblages along an experimental gradient of nutrient enrichment. Aquatic Botany 78(2):103-117 DOI 10.1016/j.aquabot.2003.09.008.

Koch M, Bowes G, Ross C, Zhang X. 2013. Climate change and ocean acidification effects on seagrasses and marine macroalgae. Global Change Biology 19(1):103-132 DOI 10.1111/j.1365-2486.2012.02791.x.

Lawrence JM. 1975. On the relationships between marine plants and sea urchins. Oceanography and Marine Biology, An Annual Review 13:213-286.

Lotze HK, Worm B. 2000. Variable and complementary effects of herbivores on different life stages of bloom-forming macroalgae. Marine Ecology-Progress Series 200:167-175 DOI 10.3354/meps200167.

Lugliè A, Satta C, Padedda B, Pulina S, Sechi N. 2008. What is Chrysophaeum taylorii Lewis \& Bryan doing in Sardinia (Tyrrhenian Sea, Mediterranean)? Harmful Algae News 36:4-5.

McGlathery KJ. 2001. Macroalgal blooms contribute to the decline of seagrass in nutrient-enriched coastal waters. Journal of Phycology 37(4):453-456 DOI 10.1046/j.1529-8817.2001.037004453.x.

Millero FJ, Woosley R, Ditrolio B, Waters J. 2009. Effect of ocean acidification on the speciation of metals in seawater. Oceanography 22(4):72-85

DOI 10.5670/oceanog.2009.98.

Mingazzini M, Thake B. 1995. Summary and conclusions of the workshop on marine mucilages in the Adriatic Sea and elsewhere. Science of Total Environment 165(13):9-14 DOI 10.1016/0048-9697(95)04538-C. 
Misic C, Schiaparelli S, Covazzi Harriague A. 2011. Organic matter recycling during a mucilage event and its influence on the surrounding environment (Ligurian Sea, NW Mediterranean). Continental Shelf Research 31(6):631-634 DOI 10.1016/j.csr.2010.12.016.

Müller WEG, Riemer S, Kurelec B, Smodlaka N, Puskaric S, Jagic B, Müller-Niklas G, Queric NV. 1998. Chemosensitizers of the multixenobiotic resistance in amorphous aggregates (marine snow): etiology of mass killing on the benthos in the Northern Adriatic? Environmental Toxicology and Pharmacology 6(4):229-238 DOI 10.1016/S1382-6689(98)00039-8.

Obernosterer I, Herndl GJ. 1995. Phytoplankton extracellular release and bacterial growth: dependence on the inorganic N: P ratio. Marine Ecology Progress Series 116:247-257 DOI 10.3354/meps116247.

Pedersen MF, Borum J. 1996. Nutrient control of algal growth in estuarine waters. Nutrient limitation and the importance of nitrogen requirements and nitrogen storage among phytoplankton and species of macroalgae. Marine Ecology Progress Series 142:261-272 DOI 10.3354/meps142261.

Piazzi L, Bulleri F, Ceccherelli G. 2016. Limpets compensate sea urchin decline and enhance the stability of rocky subtidal barrens. Marine Environmental Research 115:49-55 DOI 10.1016/j.marenvres.2016.01.009.

Reynolds SC. 2007. Variability in the provision and function of mucilage in phytoplankton: facultative responses to the environment. Hydrobiologia 578(1):37-45 DOI 10.1007/s10750-006-0431-6.

Rinaldi A, Vollenweidera RA, Montanari G, Ferrari CR, Ghetti A. 1995. Mucilages in Italian seas: the Adriatic and Tyrrhenian Seas, 1988-1991. Science of the Total Environment 165(1-3):165-183 DOI 10.1016/0048-9697(95)04550-K.

Rodríguez SR, Ojeda FP, Inestrosa NC. 1993. Settlement of benthic marine invertebrates. Marine Ecology-Progress Series 97:193-207 DOI 10.3354/meps097193.

Sala E, Ballesteros E, Dendrinos P, Di Franco A, Ferretti F, Foley D, Fraschetti S, Friedlander A, Garrabou J, Güçlüsoy H, Guidetti P, Halpern BS, Hereu B, Karamanlidis AA, Kizilkaya Z, Macpherson E, Mangialajo L, Mariani S, Micheli F, Pais A, Riser K, Rosenberg AA, Sales M, Selkoe KM, Starr R, Tomas F, Zabala M. 2012. The structure of mediterranean rocky reef ecosystems across environmental and human gradients, and conservation implications. PLOS ONE 7(2):e32742 DOI 10.1371/journal.pone.0032742.

Sala OE, Chapin FS, Armesto JJ, Berlow E, Bloomfield J, Dirzo R, Huber-Sanwald E, Huenneke LF, Jackson RB, Kinzig A, Leemans R, Lodge DM, Mooney HA, Oesterheld M, Poff NLR, Sykes MT, Walker BH, Walker M, Wall DH. 2000. Global biodiversity scenarios for the year 2100. Science 287(5459):1770-1774 DOI 10.1126/science.287.5459.1770.

Schaffelke B, Heimann K, Marshall PA, Ayling AM. 2004. Blooms of Chrysocystis fragilis on the Great Barrier Reef. Coral Reefs 23(4):514-514 DOI 10.1007/s00338-004-0439-1.

Scheffer M, Carpenter S, Foley JA, Folke C, Walker B. 2001. Catastrophic shifts in ecosystems. Nature 413:591-596 DOI 10.1038/35098000. 
Scheibling R. 1986. Increased macroalgal abundance following mass mortalities of sea urchins (Strongylocentrotus droebachiensis) along the Atlantic coast of Nova Scotia. Oecologia 68(2):186-198 DOI 10.1007/BF00384786.

Schiaparelli S, Castellano M, Povero P, Sartoni G, Cattaneo-Vietti R. 2007. A benthic mucilage event in North-Western Mediterranean Sea and its possible relationships with the summer 2003 European heatwave: short term effects on littoral rocky assemblages. Marine Ecology 28(3):341-353 DOI 10.1111/j.1439-0485.2007.00155.x.

Smith JE, Hunter CL, Smith CM. 2010. The effects of top-down versus bottom-up control on benthic coral reef community structure. Oecologia 163(2):497-507 DOI 10.1007/s00442-009-1546-z.

Smith VH, Schindler DW. 2009. Eutrophication science: where do we go from here? Trends in Ecology \& Evolution 24(4):201-207 DOI 10.1016/j.tree.2008.11.009.

Sotka EE, Hay ME. 2009. Effects of herbivores, nutrient enrichment, and their interactions on macroalgal proliferation and coral growth. Coral Reefs 28(3):555-568 DOI 10.1007/s00338-009-0529-1.

Teichberg M, Fox SE, Aguila C, Olsen YS, Valiela I. 2008. Macroalgal responses to experimental nutrient enrichment in shallow coastal waters: growth, internal nutrient pools, and isotopic signatures. Marine Ecology Progress Series 368:117-126 DOI 10.3354/meps07564.

Underwood AJ. 1980. The effects of grazing by gastropods and physical factors on the upper limits of distribution of intertidal macroalgae. Oecologia 46(2):201-213 DOI 10.1007/BF00540127.

Underwood AJ. 1997. Experiments in ecology: their logical design and interpretation using analysis of variance. Cambridge: Cambridge University Press.

Vinebrooke RD, Cottingham KL, Norberg MS, Dodson SI, Maberly SC, Sommer U. 2004. Impacts of multiple stressors on biodiversity and ecosystem functioning: the role of species co-tolerance. Oikos 104(3):451-457

DOI 10.1111/j.0030-1299.2004.13255.x.

Worm B, Sommer U. 2000. Rapid direct and indirect effects of a single nutrient pulse in a seaweed-epiphyte-grazer system. Marine Ecology Progress Series 202:283-288 DOI 10.3354/meps202283.

Zeidberg LD, Robinson BH. 2007. Invasive range expansion by the Humboldt squid, Dosidicus gigas, in the eastern North Pacific. Proceedings of the National Academy of Sciences of the United States of America 104(31):12948-12950 DOI 10.1073/pnas.0702043104. 